\title{
Türk Pozitif Hukukuyla Mukayeseli Olarak Modernleşme Dönemi Osmanlı Ceza Hukukunda İçtima: Hakaret Suçu Örneği
}

\author{
Comparative Analysis of the Aggregation of Offences under Ottoman Criminal Law during \\ the Modernization Period and Current Turkish Positive Law: A Case Study of Insult
}

\author{
Muhammed Emin Kızılay*๑
}

Öz

Yargı alanında Hanefî fikhının uygulama alanı bulduğu Osmanlı Devleti, Batı etkisiyle birlikte bu alandaki birikimini kanunlaştırmaya başlamıştır. Böylece yeni birtakım kavramlar ve teknik konular da Osmanlı hukuk diline girmiştir. Bunlardan bir tanesi içtimadır. Birden fazla suçun tek bir kişide toplanmasını ifade eden bu terim, Hanefi fikhındaki tedâhül kavramına yakın bir anlam ifade etmektedir. Fakat her iki hukuk sisteminin konuyu ele alışında farklııklar vardır. Tanzimat Dönemi'nde yaşanan kanunlaştırma faaliyetlerinde genel olarak Hanefî fikhına bağlı kalınmaya çalışımışsa da içtima gibi bazı teknik konularda fikhî birikim göz ardı edilmiştir. Bu durum dönemin yargı uygulamasında da görülmektedir. Döneme ait dava kayıtlarına ulaşmada ise 1286/1869 yılında toplumu bilgilendirerek örneklik teşkil etmesi için yayımlanan Vakâyi-i Zabtiyye gazetesi önemli bir kaynaktır. Çalışmada gazetenin yayımlandığı dönemde yürürlükte olan 1274/1858 tarihli Ceza Kanunnâmesi, dava kayıtları ve günümüz Türk pozitif hukuku üzerinden içtima sistemi karşılaştırmalı olarak ele alınacaktır. Konunun sınırlandırılması için de içtima sistemi sadece hakaret suçlarıyla ilgili dava kayıtları üzerinden incelenecektir.

\section{Anahtar Kelimeler \\ Hakaret Suçu, İçtima, Tedâhül, Ceza, Osmanlı Hukuku}

\begin{abstract}
Under western influence, the Ottoman Empire began the practice of accumulation of legislation in its judicial system. Thus, certain new concepts and technical issues, such as the aggregation of offences (ijtima), were coined in Ottoman legal jargon. This concept, which attributes more than one crime to an individual, has similar meaning to tadahul in Hanafi figh. However, there is a major difference between the two legal systems. Although the Ottoman judicial system generally tried to abide by Hanafi figh in its legislative activities during the Tanzimat period, it deviated from the fiqh system on some technical issues. To clearly consider this situation in practice, it is necessary to look at the court records of the period. Vakâyi-i Zabtiyye newspaper, which was in publication from 1286 to 1869, is an important source, as it contains court records of the period. In this study, the aggregation system in the Ottoman Criminal Code, dated 12741858 , which was in force at the time the newspaper was published, will be analysed. It will be compared with the case records under current Turkish positive law. The scope of the study is limited to the aggregation of offences through case records related to insult crime.
\end{abstract}

\section{Keywords}

Insult, Aggregation of Offences (ijtima), Tedahul, Punishment, Ottoman Law

\footnotetext{
** Sorumlu Yazar: Muhammed Emin Kızılay (Arş. Gör. Dr.), Bayburt Üniversitesi, illahiyat Fakültesi, Temel İslam Bilimleri Bölümü, Bayburt, Türkiye. E-posta: eminkizilayzade@hotmail.com ORCID: 0000-0002-2082-0597

Attf: Muhammed Emin Kizilay, "Türk Pozitif Hukukuyla Mukayeseli Olarak Modernleşme Dönemi Osmanlı Ceza Hukukunda İçtima: Hakaret Suçu Örneği." darulfunun ilahiyat 32, 2 (2021): 457-481. https://doi.org/10.26650/di.2021.32.2.994214
} 


\section{Extended Summary}

The modernization of the Ottoman Empire resulted in several innovations in the fields of jurisdiction and law. During the Tanzimat period, one of the innovations included the accumulation of legislation, which was similar to the Hanafi fiqh system, for which casuistry was abided by in the Classical period. Even though it was similar to the Hanafi fiqh, there were certain points of digression. For instance, insult, which represents crimes against a person's honour and dignity in Turkish positive law today, was also part of the first Penal Code (1256-1840 Criminal Code), which was enacted during the Tanzimat period. It moved from the fact that shariah aims to protect a person's dignity and honour and it imposes various penal sanctions on those who commit these offences. In the Kânûn-i Cedîd dated 1267-1851, the content about the offence of insult was similar to the previous law; however, this law is a text where fiqh terms were used more frequently, and it was relatively similar to the Hanafi fiqh system. In the Penal Code dated 1274/1858, offences of insult were tailored according to the French Penal Code, and the role of fiqh in preparing this law was to inspect whether the articles in the law were in accordance with shariah or not. Therefore, fiqh played a less decisive role in the legislative activities in which it was previously very influential. Moreover, the law texts, which are prepared using western ideals, do not offend against shariah. Thus, in relation to certain technical matters, some western practices were directly adopted as part of the system. For this reason, fiqh did not play a decisive role on these technical matters. An example is the term "aggregation (ijtima)" in Turkish positive law, which means the connecting and gathering of two or more crimes and punishments. Aggregation (ijtima) was adopted in the Turkish judicial system during the Tanzimat period, and although it was not a recognized term in legal texts, the system was used in court judgments. Within this framework, certain regulations were made in the 1879 Code of Criminal Procedures regarding the method to be followed in case of the aggregation of more than one offence against an individual. The Ottoman jurisprudence of the period discussed the matter at length by citing the practices all over the world. However, there were discussions regarding whether this system was a part of fiqh and whether it was in accordance with shariah or not. Such discussions only became apparent after one and a half century in contemporary Islamic Law studies. As a matter of fact, in these studies, theoretical comparisons of today's law and fiqh in the Tanzimat period were made, during which the transition process from shariah to secular law was ignored. Tedahul was the term used to describe the provisions to be applied in cases where a person commits more than one offence. Despite their common traits, the viewpoints and fundamental philosophies of tedahul and the aggregation system are distinct. In relation to fiqh, the person whose dignity has been hurt is of central importance. Thus, when personal rights (huquq al-ibad) are harmed through more than one offence, the punishment to be given is a single one. This is because personal rights are considered weaker than public rights (huquq Allah) and are therefore in need of more protection. In the aggregation system of the Tanzimat period, when offences of same or different 
types were committed against a single person or multiple people, the light punishment stipulated in the law was considered an aggravating circumstance for the severe penalty. With the Code of Criminal Procedures of 1879, it was acknowledged that the most severe of the stipulated punishments would be meted out and the light one would already be included in the severe one. Nevertheless, in today's Turkish positive law, unlike the Ottoman positive law, the offences are aggregated. In this system, rather than aggregating different penalties stipulated for each crime, the violation of multiple norms caused by one or more acts is considered a single crime. In this system, similar to fiqh, legal dignity affected by the offence is ignored, and many types of violations of norms are aggregated as much as possible. In this way, it can be understood that the suffering of the victim is ignored in favour of the criminal. 


\section{Giriş}

Hakaret suçu, günümüz Türk pozitif hukukunda şerefe karşı işlenen ifade etmek için kullanılmaktadır. Bu suç, Osmanlı pozitif hukukunda şetm, klasik Hanefî fikhında ise şetm, sebb gibi tabirlerle ifade edilmiştir. ${ }^{1}$ Gerek Hanefî fikhında gerek Tanzimat sonrası Osmanlı pozitif hukukunda ve gerekse günümüz Türk pozitif hukukunda kişinin manevi varlığına zarar veren fiiller suç sayılmış ve çeşitli cezai yaptırımlar düzenlenmiştir. Her üç hukuk sisteminde hakaret suçunun cezalandırılmasıyla korunan hukuki değer kişinin manevi varlığı, namus ve şerefidir. ${ }^{2}$ Tarihî olarak bu üç sistemin bağlantı noktası ise Tanzimat Dönemi'dir. Zira bu dönem, Hanefî fikhından seküler hukuka geçişin yaşandığı ve bu değişimin gözlemlenebileceği bir dönemdir. Çalışmada bu değişim, Batı hukuk sistematiğinin benimsenmeye başlamasıyla hukuk dilimize giren içtima sistemi ve bu sistemin uygulandığı hakaret suçları üzerinden görülmeye çalış1lacaktır. Bunun için hem dönemin kanunları hem de bu kanunların uygulama alanı bulduğu yargılamalara ait dava kayıtları incelenecektir. Dönemin dava kayıtlarına ulaşmada yaşanan zorluğu aşmak için 1286/1869 yılında yayımlanmaya başlayan ve mahkeme tutanaklarına da yer veren Vakâyi-i Zabtiyye Gazetesi'nden yararlanılacaktır. ${ }^{3}$ Gazetede hakaret (şetm) suçu ve bu suça verilen bazı cezalarda, bugün Türk pozitif hukukunda suçun özel görünüş şekillerinden biri kabul edilen içtima sisteminin izlerini görmek mümkündür. Bu sebeple Türk pozitif hukuku ve Hanefî fikhı açısından içtima sistemi ele alınıp gazetede bu sistem ile ilgili örnekler mukayeseli bir şekilde tahlil edilecektir.

F1khî açıdan tedâhül/içtima ile ilgili günümüzde yapılan çalışmalarda mezheplerin konu ile ilgili görüşlerine yer verilmekte ve konu günümüz Türk pozitif hukukuyla

1 Ebû Bekr Muhammed b. Ebî Sehl Ahmed es-Serahsî, el-Mebsût (Beyrut: Dâru'l-Marife, 1993), 24:36; Kemalüddin İbnü'l-Hümâm, Feth'ul-kadîr (Beyrut: Dâru'l-Fikr, 1970), 5:353; Mehmed b. Ferâmuz Molla Hüsrev, Dürerü'l-hükkâm şerhu gureri'l-ahkâm (Dâr-u İhyai'lKütübi'l-Arabî, t.y.), 2:76; Zeynüddin İbn Nüceym, Bahru'r-râik şerhu kenzi'd-dekāik (Tekmiletü Tûrî ve Minhatü'l-hâlik ile Birlikte) (Kahire: Dâru'l-Kitâbi'l-İslâmî, t.y.), 5:47; Mehmet Boynukalın, “Sövme”, içinde TDV Íslam Ansiklopedisi (İstanbul: TDV Yayınları, 2009), 398; Ceza Kanunnâme-i Humâyunu (İstanbul: Matbaa-1 Osmâniye, 1300), 100.

2 Bedruddin el-Aynî, el-Binâye şerhu'l-Hidâye (Beyrut: Dâru'l-Kütübi'l-İlmiyye, 2000), 6:391; İbnü'l-Hümâm, Feth 'ul-kadîr, 5:347; Molla Hüsrev, Dürer, 2:76; Abdurrahman b. Muhammed b. Süleyman Damad Efendi, Mecmau'l-enhur fì şerhi mülteka'l-ebhur (Beyrut: Dâru İhyai'tTurasi'l-Arabî, t.y.), 1:609-610; Diran Yerganyan, Kanun-ı Ceza Dersleri, 2. bs (Dersaadet: Becidyan Matbaas1, 1326), 1:238; Artin Boşgezenyan, Kanun-ı Cezanın Mevâdd-ı Kâime ve Muaddelesi Hakkında Teşrih ve Tenkit (İstanbul: Matbaa-1 Âmire, 1327), 214; Mahmut Koca ve İlhan Üzülmez, Türk Ceza Hukuku Özel Hükümler (Ankara: Adalet Yayınevi, 2013), 425.

3 Gazeteye ait ilk elli sayı, Milli Kütüphane'nin internet sayfasında mevcut olup elektronik olarak erişim mümkündür. Bkz.: https://dijital-kutuphane.mkutup.gov.tr/tr/periodicals/catalog/ details/821 
mukayeseli olarak ele alınmaktadır. ${ }^{4}$ Bazılarında ise konu Tanzimat Dönemi ceza hukuku alanında yaşanan değişiklikler üzerinden incelenmektedir. ${ }^{5} \mathrm{Bu}$ çalışmalardan hareketle fikıhta bugünkü içtima sistemine benzer bir sistemin var olduğu lakin Tanzimat ile birlikte fıkhî birikimin göz ardı edilmesi sebebiyle bu birikimin görmezden gelindiği söylenebilir. Dönemin Osmanlı hukukçuları da konuyu klasik fikıhtan ziyade Batı hukuk sistemlerinden hareketle ele almışlardır. Bu süreç zamanla fikhın tamamen terk edilmesi ve seküler hukuka geçişle sonuçlanmıştır. Çalışmada mezkûr geçiş süreci içtima konusu üzerinden ele alınacaktır. Fakat konu sadece nazari olarak değil, uygulama üzerinden takip edilecektir. Bu vesileyle uygulama ve nazariye arasındaki bağ tespit edilmeye çalışılacaktır. Ayrıca günümüz Türk ceza hukuku da sürecin son halkası olduğundan ve günümüzde kullanılan kavramlar Tanzimat Dönemi Osmanlı pozitif hukukuna dayandığından konu, günümüz ceza hukuku ile mukayeseli olarak ele alınacaktır.

\section{Türk Hukuk Tarihinde Hakaret Suçu}

Hanefî fikhında kutsal değerlere sövme ve iffetli kişiye zina isnadında bulunma gibi bazı suçlar haricindeki sövgü ifadeleri ta 'zir cezası gerektiren suçlar kapsamında ele alınmıştır. ${ }^{6}$ Örneğin bir başkasına "fasık", "zındık”, "köpek” "zalim", "yalan şahidi" gibi ifadeler kullanılması suç sayılmış ve bu suç için ta'zir cezası öngörülmüştür. ${ }^{7}$ Klasik dönem Osmanlı'da bu tür suçlar için ta'zir kapsamında dayak ve hapis cezaları verilmiştir. ${ }^{8}$ Ayrıca bu suçların sadece şifahen

4 Örnek iki çalışma için bkz.: Sabri Erturhan, İslam Ceza Hukukunda İçtima (İstanbul: Rağbet Yayınları, 2003); Mustafa Avcı, “İslam ve Osmanlı Ceza Hukukunda İçtima”, Kırıkkale Hukuk Mecmuası 1, sy 1 (2021): 1-30.

5 Kübra Nugay, “XIX. Yüzyıl Ortak Ceza Hukuku Dilinin Oluşumu: Osmanlı'da Ta'zîrin Kalkması” (Doktora Tezi, İstanbul, Marmara Üniversitesi Sosyal Bilimler Enstitüsü, 2020).

6 Serahsî, el-Mebsût, 24:36; Aynî, el-Binâye, 6:395; İbnü'l-Hümâm, Feth'ul-kadîr, 3:353; Lisânüddin İbnü'ş-Şıhne, Lisânü'l-hükkâm fî ma 'rifeti 'l-ahkâm (Kahire: el-Bâbî el-Halebî, 1973), 258; Molla Hüsrev, Dürer, 2:76; İbn Nüceym, Bahru'r-râik, 5:147; Damad Efendi, Mecmau'l-enhur, 1:697; Alâüddîn Muhammed b. Alî b. Muhammed Haskefî, ed-Dürrü 'l-muhtâr şerhu tenvîri'l-ebsâr ve Câmii'l-bihâr (Beyrut: Dâru'l-Kütübi'l-İlmiyye, 2002), 319; Tuncay Başoğlu, “Ta'zir”, içinde TDV İslam Ansiklopedisi (İstanbul: TDV Yayınları, 2011), 199.

7 Aynî, el-Binâye, 6:391; İbnü'l-Hümâm, Feth'ul-kadîr, 5:347; Molla Hüsrev, Dürer, 2:76; Damad Efendi, Mecmau'l-enhur, 1:609-610; Şeyhülislam Çatalcalı Ali Efendi, Açıklamalı Osmanlı Fetvaları, ed. H. Necati Demirtaş (İstanbul: Kubbealtı Neşriyat, 2011), 245-50; Şeyhülislam Feyzullah Efendi, Fetava-yı Feyziye. (İstanbul: Klasik Yayınları, 2009), 114-15; H. Necati Demirtaş, Fetvaları ile Şeyhülislam Ebüssu'ud Efendi (İstanbul: Akıl Fikir Yayınları, 2016), 571-72.

8 Mehmet Koç, “Osmanlı Hukukunda Ta 'zir Suç ve Cezaları” (Doktora Tezi, Konya, Necmettin Erbakan Üniversitesi Sosyal Bilimler Enstitüsü, 2017), 215. 
değil, çeşitli beden hareketleriyle, yazı ve neşir yoluyla da gerçekleşebileceği kabul edilmiştir. ${ }^{9}$

Tanzimat ile birlikte Osmanlı Devleti'nde yaşanan değişikliklere paralel olarak hukukun çeşitli alanlarında kanunlaştırma faaliyetleri başlamıştır. Hakaret suçu ile ilgili düzenlemeler de 1256/1840 yılında yapılan dönemin ilk ceza kanununda yer almıştır. ${ }^{10}$ Daha sonra 1267/1851 tarihli Kanun-1 Cedîd yürürlüğe girmiş, bu kanunda hakaret suçu ile ilgili öncekine nazaran fazla bir değişiklik yapılmamıştır. ${ }^{11}$ Son olarak 1274/1858 tarihinde yeni bir ceza kanunu yürürlüğe girmiştir. Bu kanunun, öncülü iki kanundan farkı ise muhteva olarak milli kabul edilmekle birlikte Batı kanun sistematiği takip edilerek yapılmış olmasıdır. ${ }^{12}$ Kanun 1911 yılında büyük bir değişikliğe uğramış, özellikle hakaret suçları ile ilgili madde daha teknik ve detaylı bir şekilde kaleme alınarak maddeye gerekçe de eklenmiştir. ${ }^{13}$ Gazetenin yayımlandığı dönemde yürürlükte olan kanun, 1274/1858 Ceza Kanunnâmesi’nin değişikliğe uğramamış hâli olduğundan çalışmada Kanun'un bu hâli esas alınacaktır. Bununla birlikte hakaret suçu ile ilgili maddenin ve bu maddede kullanılan terimlerin anlaşılması için ilgili maddenin 1911 yılında değişikliğe uğramış hâlinden de istifade edilecektir. 1274/1858 Ceza Kanunnâmesi'nde "Eşhâs Hakkında Vuku Bulan Cinayet ve Cünhalarla Mücazât-1 Müterettibeleri" isimli ikinci bölümün "İftira ve Şetm ve İfşa-yı Sır Beyanındadır” isimli altıncı faslındaki 214. maddesinde hakaret suçları düzenlemiştir:

Bir mâdde-i mahsûsa isnadı olmayıp fakat me âyibden bir şey tahsisiyle ya diğer suretle bir kimse diğer kimse hakkında muhill-i namus söz söyler veyahut şetm eyler ise yirmi dört saatten bir aya kadar hapis olunur. Veyahut buna bedel yarım mecidiye altınından üç mecidiye altınına kadar ceza-yı nakdî alınır. ${ }^{14}$

9 Ömer Nasuhi Bilmen, Hukūk-ı İslâmiyye ve Istılâhât-ı Fıkhiyye Kāmusu (İstanbul: Ravza Yayınları, 2013), 3:321.

10 Ahmet Akgündüz, Ceza Kanunnâme-i Humâyûnu (Mukayeseli İslâm ve Osmanlı Hukuku Külliyatı İçerisinde) (Diyarbakır: Dicle Üniversitesi Hukuk Fakültesi Yayınları, 1986), 812.

11 Ahmet Lütfi, Kanun-ı Cedîd (Mirât-ı Adalet İçerisinde) (İstanbul: Matbaa-i Nişân Berberyan, 1304), 159-60.

12 Mehmet Gayretli, Tanzimat'tan Cumhuriyet'e Kanunlaştırma Çalışmaları (İstanbul: Nizamiye Akademi, 2015), 229, 233.

13 Tevfik Tarık, Yeni Kanun-ı Ceza (Dersaadet: Şems Matbaası, 1329), 159; Mehmet Âkif Aydın, "Batılılaşma", içinde TDV İslam Ansiklopedisi (İstanbul: TDV Yayınları, 1992), 482; Mustafa Şentop, Tanzimat Dönemi Osmanlı Ceza Hukuku: Kanunlar-Tadiller-Layihalar-Uygulama (İstanbul: Yaylacık Matbaası, 2004), 109; Gayretli, Tanzimat 'tan Cumhuriyet'e Kanunlaştırma Çalışmaları, 242.

14 Ceza Kanunnâme-i Humâyunu, 100. 
Maddede hakaret suçları "şetm" ve "muhill-i namus söz söyleme" şeklinde ifade edilmiştir. Şetm kelimesi sövmek, küfretmek anlamlarına gelmektedir. ${ }^{15}$ "Muhill-i namus söz söyleme" ifadesi ise namusu ihlal edici söz anlamında olup dönemin hukukçuları tarafından bir kimsede olmayan özellikleri o kişiye isnat etmek şeklinde açıklanmıştır. ${ }^{16}$ Her ne kadar kanun maddesinde açıklanmasa da bu suçun sözlü gerçekleşebileceği gibi yazılı olarak da gerçekleşebileceği kabul edilmiştir. ${ }^{17}$ Gazetenin 19 Recep 1286 (25 Ekim 1869) tarihli kırk üçüncü sayısında yer alan bir dava kaydında üç şahsın, muhill-i namus bir mektup kaleme alarak mektubu bir başka kişiye göndermeleri sebebiyle 214. madde gereğince on beşer gün hapis cezası aldıkları ifade edilmektedir. ${ }^{18}$ İlgili kanun maddesinde suçun yazılı olarak da gerçekleşebileceğine dair bir ifade bulunmamakla birlikte mahkeme, suçun yazılı olarak gerçekleşmesi hâlinde de korunan hukuki değerin zedelendiği kanaatine varmıştır. Yine gazetede suçun şifahen gerçekleşmesinin yanında birtakım hareketlerle de gerçekleştiğine dair dava kayıtlarına rastlamak mümkündür. Örneğin 26 Safer 1286 (7 Haziran 1869) tarihli dördüncü sayıda, bir başkasının "namusuna dokunur harekette" bulunan şahsa, "214. maddeye kıyasen" yirmi dört saat hapis cezası verildiğine dair bir dava kaydı yer almaktadır. ${ }^{19}$ Dikkat edilirse mahkeme vermiş olduğu cezayı 214. maddeye kıyas ederek vermiştir. 1911 tarihinde ilgili kanun maddesinde yapılan değişiklikle suçun yazılı olarak ve çeşitli beden hareketleriyle gerçekleşebileceği de kanun metnine eklenmiştir. ${ }^{20}$

Maddede geçen mâdde-i mahsûsa tabirinden ne kastedildiği tam olarak açıklanmamakla birlikte, Kanunnâme'nin 1911 yılında geçirdiği değişiklik üzerine yapılan şerh çalışmalarında bu tabir detaylıca ele alınmıştır. Buna göre mâdde-i mahsûsa isnadı, bir isnadın zaman, mekân tayiniyle ve üçüncü bir kişi ile irtibatlandırılarak yapılmasıdır. Örneğin birine yönelik hırsızlık isnadı, hırsızlığın ne zaman, nereden ve kimden yapıldığı gibi detayları içeriyorsa bu, mâdde-i mahsûsa

15 TDK Sözlükleri, “Şetim” (Erişim 10 Ağustos 2021); Kubbealtı Lügati, "Şetm” (Erişim 10 Ağustos 2021).

16 Mehmed Reşâd, Mi'yâr-ı Ceza: Kanun-ı Ceza Şerhi (İstanbul: Dâru't-Tıbâati'l-Âmire, 1303), 414.

17 Sami Bey, Mirât-ı Kanun-ı Ceza: Kanun-ı Ceza Şerhi, 2. bs (Dersaadet: Matbaa-i Kütübhane-i Cihan, 1324), 340.

18 Vakâyi-i Zabtiye, 43/3, M.T. Dersaâdet.

19 Vakâyi-i Zabtiye, 4/3, M.T. Beyoğlu; Hareket yoluyla gerçekleşen suçlarla alakalı benzer dava kayıtları için bkz.: Vakâyi-i Zabtiye, 7/3, M.T. Beyoğlu; 7/4 M.T. Üsküdar; 24/4 M.T. Beyoğlu; 47/4 M.T. Üsküdar.

20 Tevfik Tarık, Yeni Kanun-ı Ceza, 159-61. 
isnat etmektir. ${ }^{21} \mathrm{Bu}$ tabir, 765 sayılı mülga TCK'de de aynen kullanılmıştır. (md. 480) 1274/1858 tarihli Kanunnâme'de "bir madde-i mahsûsa isnadı olmayı" ifadesi yer aldığından, bu tür isnatların hakaret suçu kapsamında değerlendirilmediği anlaşılmaktadır. Lakin Kanunnâme' de yapılan değişiklikle bu tür suçlar da hakaret suçu kapsamına alınmış ve zem suçu olarak tanımlanmıştır. ${ }^{22}$

Hakaret suçları günümüz Türk pozitif hukukunda seçimlik hareketli bir suç olarak kabul edilmektedir. Bu hareketlerden biri somut bir fiil veya olgu isnadı, diğeri ise sövme fiilidir. (TCK md.125/1) Fiilin veya olgunun somut olmasından maksat, isnadın kişi, zaman ve belirli bir şahıs ile bağlantılı olarak gerçekleşmesidir. ${ }^{23} \mathrm{Bu}$ sebeple somut bir fiil/olgu isnadının, Osmanlı pozitif hukukundaki mâdde-i mahsûsa tabiriyle büyük oranda aynı anlamda kullanıldığı söylenebilir. Hakaret suçunun bu seçimlik hareketi, 1274/1858 Ceza Kanunnâmesi'nin geçirdiği değişiklikle birlikte Türk hukuk tarihinde hakaret suçu kapsamına girmiş̧tir. Çalışmada ele alınan gazete, Kanunnâme'de yapılan değişiklikten önce yayımlanmaya başladığından gazetede yer alan dava kayıtlarındaki hakaret suçları, somut fiil/olgu isnadını kapsamamaktadır. Türk pozitif hukukunda suçun diğer seçimlik hareketi sövme ise "kişinin onuruna, şerefine ve saygınlığına yönelik olumsuz değer yargılarında bulunmayı ifade etmektedir.” Bu tür hakaret suçlarında soyut bir fiil/olgu isnadı söz konusu olmaktadır. ${ }^{24}$ Değişikliğe uğramamış hâliyle 1274/2858 Ceza Kanunnâmesi'nde şetm suçu olarak düzenlenen suçun, Türk pozitif hukukunda hakaret suçunun seçimlik hareketlerinden sövmeye karşılık geldiği anlaşılmaktadır. Türk pozitif hukukunda da hakaret suçunun sesli ve yazılı olarak gerçekleşebileceği kabul edilmektedir. (TCK md.125/2)

Suçun nitelikli hâllerinden biri olarak ifade edilen, hakaretin kamu görevlisine yönelik icra ettiği görev sebebiyle işlenmesi (TCK md.125/3-a) 1274/1858 Ceza

21 Yerganyan, Kanun-ı Ceza Dersleri, 1:239; Boşgezenyan, Kanun-ı Cezanın Mevâdd-ı Kâime ve Muaddelesi Hakkında Teşrih ve Tenkit, 214.

22 Tevfik Tarı, Yeni Kanun-ı Ceza, 159.

23 Koca ve Üzülmez, Türk Ceza Hukuku Özel Hükümler, 432-34; Recep Doğan, "Hakaret Suçu ve AİHM Kararlarında İfade Özgürlüğünün Sınırları”, Uyuşmazlık Mahkemesi Dergisi, sy 17 (2021): 201-3; Devrim Aydın, “Türk Ceza Kanunu'nda Hakaret Suçu”, Marmara Üniversitesi Hukuk Fakültesi Hukuk Araştırmaları Dergisi 19, sy 2 (2013): 889; Bülent Tatar, “Türk Ceza Hukukunda Hakaret Suçları (Şerefe Karşı Suçlar)” (Doktora Tezi, İstanbul, Marmara Üniversitesi Sosyal Bilimler Enstitüsü, 2009), 42; Enes Köken, "Şerefe Karşı Suçlar”, Uyuşmazlık Mahkemesi Dergisi, sy 6 (2016): 291-92.

24 Koca ve Üzülmez, Türk Ceza Hukuku Özel Hükümler, 434; Doğan, "Hakaret Suçu ve AİHM Kararlarında İfade Özgürlüğünün Sınırları”, 203; Aydın, “Türk Ceza Kanunu'nda Hakaret Suçu”, 889; Tatar, "Türk Ceza Hukukunda Hakaret Suçları (Şerefe Karşı Suçlar)”, 42; Köken, "Şerefe Karşı Suçlar”, 292. 
Kânunnâmesi'nde şetm suçunu düzenleyen 214. maddeden ayrı olarak 113. maddede ele alınmıştır. ${ }^{25}$ Her iki maddede öngörülen cezalar kıyaslandığında suçun memura karşı işlenmiş olmasının ceza artırım sebebi sayılmadığı anlaşılmaktadır. Gazetede memura yönelik hakaret suçlarıyla ilgili örnek dava kayıtları mevcuttur. Bunlardan biri, 18 Rebîülevvel 1286 (28 Haziran 1869) tarihli onuncu sayıda yer almaktadır. Dava kaydında aktarıldığına göre bir zaptiye mülazımına laf atarak namusuna dokunan şahsa Ceza Kanunnâmesi'nin 113. maddesi gereğince bir adet yüzlük nakit para cezası verilmiştir. ${ }^{26}$

Günümüz Türk pozitif hukukunda bazı durumlarda hakaret suçu için öngörülen cezanın tamamen veya kısmen düşürülebileceği kabul edilmektedir. Bunlardan biri karş11ıklı hakarettir. Hakaretin suçunun karşı1ıklı işlenmesi durumunda mahkeme, somut olaya göre taraflardan biri veya her ikisine verilecek cezayı tamamen veya üçte bire kadar düşürebilmektedir. (TCK md.129/3) 1274/1858 Ceza Kanunnâmesi’nin ilk hâlinde bu tür ceza indiriminden bahsedilmemekle birlikte gazetede karşı1lklı hakaret suçunun işlendiği davalara rastlanmaktadır. Örneğin 11 Cemâziyelevvel 1286 (19 Ağustos 1869) tarihli yirmi beşinci sayıda yer alan dava kaydında, iki şahsın birbirine yönelik muhill-i namus söz söylemeleri sebebiyle yargılandığı, dava sonucu taraflara "derece-i kabahatlerine göre" bir ve yarım mecidiye altın para cezası verildiği belirtilmektedir. ${ }^{27}$ Gazetede yer alan davalardaki şetm suçlarına verilen cezalar ile mukayese edildiğinde suçun karşılıklı gerçekleşmesi sebebiyle herhangi bir ceza indiriminin uygulandığı söylenemez. Dava kayıtlarında da ceza indirimi yapıldığına dair bir ibare yer almamaktadır. Buradan anlaşıldığ 1 üzere gazetenin yayımlandığ 1 dönemde şetm suçunun bir başka şetme karşıllk işlenmesi haksız tahrik kapsamında değerlendirilmemektedir. Lakin 1911 yılında yapılan değişiklikle şetm suçları üç ayrı suç türü olarak ele alınmış, bunlardan tahkir türü suçların karşılıklı işlenmesi hâlinde mahkemenin taraflardan biri veya her ikisinin cezasını üçte birden üçte ikiye kadar veya tamamen 1skat edebileceği kanunlaştırılmıştır. $^{28}$

25 “Asâkir-i nizamiyenin ve hükûmet tarafindan 'ale'l-1tlâk zabitaya ve idareye memur bulunanların memuriyetlerini icrada veyahut icra ettikleri hükmei memuriyetten dolayı kadr-ü namuslarına nakısa verecek suretle haklarında muamele-i hakarete ve itâle-i lisana ve ihâfeye cüret edenler olur ise bir mecidiye altınından üç mecidiye altınına kadar ceza-yı nakdî ahz olunur ve bu misilli hakaretler Asâkir-i Nizamiye zabıtanı ve zaptiye ser-gerdeleri haklarında vuku bulur ise bir haftadan bir aya kadar hapis olunur. Ve eğer bu misilli hakaret ve ihafenin icrasında teşhir-i silah eden olur ise her hâlde altı aydan iki seneye kadar haps olunur." Ceza Kanunnâme-i Humâyunu, 45.

26 Vakâyi-i Zabtiye, 10/3, M.T. Beyoğlu.

27 Vakâyi-i Zabtiye, 25/3, M.T. Üsküdar.

28 Tevfik Tarık, Yeni Kanun-ı Ceza, 162; Yerganyan, Kanun-ı Ceza Dersleri, 1:237; Boşgezenyan, Kanun-ı Cezanın Mevâdd-ı Kâime ve Muaddelesi Hakkında Teşrih ve Tenkit, 221-22. 


\section{Hakaret Suçu Açısından İçtima}

İçtima sistemi, modern hukukta suçun özel görünüş şekillerinden biridir. ${ }^{29}$ Türk pozitif hukukunda çeşitli ceza kanunu metinlerinde yer alan bu sistemin temeli, Tanzimat sonrası Osmanlı uygulamasına kadar dayanmaktadır. Osmanlı'da ise içtima, Batı hukuk sistemlerinden alınmıştır. Osmanlı'da resmî mezhep olarak kabul edilen ve uygulanan Hanefî fikhında, Batı hukuk sistemlerinden alındığı şekliyle bir içtima sistemi olmadığı gibi içtima, müstakil bir konu olarak da tartışılıp ele alınmamaktadır. Bu, klasik fikıhta bugün içtima kapsamında tartışılan nazari konularla ilgili örneklerin bulunmadığ 1 anlamına gelmemektedir. Aksine içtima mantığına klasik fikhın birçok konusunda rastlamak mümkündür. ${ }^{30} \mathrm{Klasik}$ kaynaklarda içtima anlayışını ifade etmek için birçok terim kullanılmakla birlikte bunlar içerisinde özellikle tedâhül kavramı öne çıkmaktadır. ${ }^{31}$ Bu kavram "iki veya daha fazla şeyin iç içe geçmesi” "32, "ayrı ayrı hükmü bulunan hukuki hadiselerin bir araya gelmesi" 33 gibi anlamlara gelmektedir. F1k1h, kazuistik metotla tedvin edildiğinden bu kavram nazariyede müstakil bir konu olarak işlenmemiş, çeşitli fikhî konuların ilgili bölümlerinde yeri geldikçe ele alınmıştır. ${ }^{34}$ Konu ile alakalı yakın dönemde ve mücerret metodla telif edilen müstakil çalışmalarda veya çeşitli çalışmalar içerisindeki müstakil başlıklarda fikhî açıdan içtima konusu ele alınmaktadır. Bu çalışmalar, fikıh nazariyesinde bugünkü içtima fikrinin çok geniş bir çerçevede ele alındığını, bu sebeple tüm suç türlerini kapsayacak genel bir içtima anlayışından ziyade her suçun kendine özgü içtima durumu olduğunu

29 Erturhan, İslam Ceza Hukukunda İçtima, 29; Mustafa Avcı, Osmanlı Ceza Hukuku Özel Hükümler, 3. bs (Ankara: Adalet Yayınevi, 2018), 186; Nugay, "XIX. Yüzy1l Ortak Ceza Hukuku Dilinin Oluşumu: Osmanlı'da Ta'zîrin Kalkması”, 173.

30 Küveyt Vakıflar ve Din İşleri Bakanlığı, el-Mevsûatü 'l-Fıkhiyyeti'l-Kuveytiyye (Kuveyt: Dârü'sSelâsil, 1404), 11:83-84; Erturhan, İslam Ceza Hukukunda İçtima, 69.

31 Taha Hamid Hasan ve Ahmed Geylan, "İslam Ceza Hukukunda ve Pozitif Hukukta Aynı Amaca Yönelik Suçların Gerçek İçtimai”, içinde İslam Ceza Hukuku, ed. Abdurrahman Eren ve Refik Korkusuz, çev. Osman Güman (İstanbul: Lale Yayıncılık, 2017), 827; Literatürde tedâhül ile aynı anlamda kullanılan terimler için bkz.: Küveyt Vakıflar ve Din İşleri Bakanlığı, el-Mevsûatü'lFikhiyyeti'l-Kuveytiyye, 11:81-82.

32 Mehmet Erdoğan, Fıkıh ve Hukuk Terimleri Sözlüğü, 4. bs (Ensar Neşriyat, 2013), 55.

33 Erturhan, İslam Ceza Hukukunda İçtima, 28.

34 Ahmed b. Ali Ebubekr er-Râzî el-Cessâs, Şerhu muhtasari 't-Tahâvî (Beyrut: Dâru'l-Beşâiri'lİslâmiyye, 2010), 2:424; Ebü'l-Hüseyn Ahmed b. Ebî Bekr Muhammed b. Ahmed el-Kudûrî, et-Tecrîd, 2. bs (Kahire: Dâru's-Selâm, 2006), 10:5252; Serahsî, el-Mebsût, 9:139; Osman b. Ali Zeylâ̂, Tebyînü'l-Hakāik Şerhu Kenzi'd-Dekāik (Şeleb̂̂'nin Hâş̧iyesiyle Birlikte) (Kahire: Dâru'l-Kitâbi'l-İslâmî, 1896), 3:207, 237; Aynî, el-Binâye, 4:55; İbnü'l-Hümâm, Feth 'ul-kadîr, 5:344; İ̉n Nüceym, Bahru'r-râik, 4:109. 
ortaya koymaktadır. ${ }^{35}$ Hiç şüphesiz bu, fikhın kazuistik metot takip edilerek tedvin edilmesi ile alakalıdır. İçtima terimi ceza hukukunda genel bir kavram olup teoride suçların ve cezaların içtimaı şeklinde iki farklı şekilde ele alınmaktadır.

\section{a- Suçların İçtimaı}

Modern ceza hukukunda aslolan kural "kaç tane fiil varsa o kadar suç, kaç tane suç varsa o kadar ceza olduğudur". ${ }^{36}$ Türk pozitif hukukunda da genel kural her bir suçun ayrı ayrı cezalandırılması ve her cezanın bağımsızlığını korumasıdır. ${ }^{37}$ Lakin bazı durumlarda istisna olarak, suçlunun ağır yaptırımlara maruz kalmasını önlemek adına işlenen suçların içtimaı kabul edilmiştir. Teoride suçların içtima1, bir veya birden fazla fiil ile meydana gelen birden çok norm ihlalinin tek bir suç olarak kabul edilmesini ifade etmektedir. Türk pozitif hukukunda ise suçların içtima1, zincirleme suç ve fikrî içtima şeklinde iki kısma ayrılmaktadır. Fikrî içtima da kendi içinde aynı neviden ve farklı neviden olmak üzere iki farklı şekilde gerçekleşebilmektedir. Ayrıca günümüz Türk pozitif hukukunda hakaret suçlarında da içtima hükümlerinin uygulanabileceği kabul edilmektedir. ${ }^{38}$

Zincirleme Suç: Bir suç işleme kararının icrası neticesinde, aynı suçun aynı kişiye karşı birden fazla işlenmesi durumudur. Burada aynı norm ihlali, tamamında tipiklik ve hukuka aykırılık unsurunun bulunduğu birden çok müstakil fiil ile müteaddit defa ve farklı zamanlarda gerçekleşmektedir. ${ }^{39}$ Yine zincirleme suç için işlenen suçların mağdurunun aynı kişi olması gerekmektedir. ${ }^{40}$ Söz gelimi değişik zamanlarda ve aynı kişiye karşı birden fazla cinsel taciz suçu işlendiğinde zincirleme suç meydana gelmektedir. ${ }^{41}$ Lakin aynı kişiye bir gün cinsel tacizde bulunulup başka bir zaman hakaret edildiğinde, farklı iki norm ihlali söz konusu olmakta ve zincirleme suç meydana gelmemektedir. Bu durumda fail, işlediği suç

35 Erturhan, İslam Ceza Hukukunda İçtima, 86-87.

36 Neslihan Göktürk, “Türk Hukuku’nda Suçların İçtimaı”, Ceza Hukuku ve Kriminoloji Dergisi 2, sy 1-2 (2014): 34.

37 Mahmut Koca ve İlhan Üzülmez, Türk Ceza Hukuku Genel Hükümler, 6. bs (Ankara: Seçkin Yayınc1l1k, 2013), 471.

38 Tatar, "Türk Ceza Hukukunda Hakaret Suçları (Şerefe Karş1 Suçlar)”, 265; Aydın, "Türk Ceza Kanunu'nda Hakaret Suçu”, 94; Köken, "Şerefe Karşı Suçlar”, 300.

39 İzzet Özgenç, Türk Ceza Hukuku Genel Hükümler, 11. bs (Ankara: Seçkin Yayıncılık, 2015), 563.

40 Koca ve Üzülmez, Türk Ceza Hukuku Genel Hükümler, 482-83; Özgenç, Türk Ceza Hukuku, 564; Göktürk, "Türk Hukuku'nda Suçların İçtimaı”, 42; Türkan Yalçın Sancar, "Yeni Türk Ceza Kanunu'nda 'Zincirleme Suç”, Türkiye Barolar Birliği Dergisi, sy 70 (2007): 249-53.

41 Erdal Baytemir, Cinsel Dokunulmazlığa, Kişi Hürriyetine ve Genel Ahlaka Karşı Suçlar (Ankara: Adalet Yayınevi, 2007), 745-46. 
sayısınca ceza almaktadır. ${ }^{42}$ Zincirleme suç gerçekleştiğinde ise faile işlemiş olduğu suçların her biri için ayrı ayrı ceza verilmemekte, bu suçlar birleştirilerek hepsi için kanunda belirtilen oranda (TCK md.43/1) arttırılmış tek bir ceza verilmektedir. ${ }^{43}$ Yürürlükten kaldırılan eski TCK'de (md. 80) ise birden çok kişiye müteaddit defa aynı suçun işlenmesi de zincirleme suç kapsamında değerlendirilmiştir. ${ }^{44}$

Fikrî Iç̧tima: Zincirleme suçtan ayrı olarak fikrî içtimada tek bir fiil bulunmaktadır. Lakin bu tek fiil ile birden çok norm ihlali meydana gelmekte, tek bir fiil ile birden çok suçun kanuni tanımı objektif olarak gerçekleşmektedir. ${ }^{45}$ Tek fiil ile aynı suçun birden fazla kişiye işlenmesi hâlinde aynı neviden fikrî içtima söz konusu olmaktadır. ${ }^{46}$ Örneğin tek bir söz ile birden fazla kişiye hakaret edilmesi durumunda aynı neviden fikrî içtima gerçekleşmektedir. Suçun tek bir fiil ile farklı kişilere karşı işlenmesi durumunda, mağdurların birden fazla olması sebebiyle taaddüt eden suçlar birleştirilmektedir. Birleştirilen suça mukabil ise kanunda belirlenen oranda (TCK md.43/2) ceza artırımına gidilmektedir.

Tek bir fiil ile birden fazla farklı suç işlendiğinde ise farklı neviden fikrî içtima söz konusu olmaktadır. Burada suçun aynı kişiye karşı işlenmiş olması gibi bir şart aranmamaktadır. Farklı neviden fikrî içtima söz konusu olduğunda her bir suç ayrı ayrı cezalandırılmamakta, suçların tek bir fiil ile gerçekleştirilmiş olmasının içtimaa imkân verdiği kabul edilmektedir. ${ }^{47}$ Böylece suçlar birleştirilmekte ve faile bu suçlar içerisinden sadece en ağır cezayı gerektiren suçun cezası infaz edilmektedir. (TCK md.44)

\section{b- Cezaların içtimaı}

Birden fazla fiil ile birden fazla hukuk normunun ihlal edilmesi durumunda fail her bir ihlale karşılık birbirinden bağımsız birden fazla cezaya mahkûm edilir. Bu durumda failin her bir fiili ayrı ve bağımsız bir suç teşkil etmektedir. Böylece suçların kaynaşması mümkün olmamakta, belki cezaların içtimaı söz konusu olabilmektedir. ${ }^{48}$ Dolayısıyla cezaların içtima edebilmesi için suçların içtima etmemiş olması, ayrıca

42 Koca ve Üzülmez, Türk Ceza Hukuku Genel Hükümler, 486-87.

43 Özgenç, Türk Ceza Hukuku, 571; Koca ve Üzülmez, Türk Ceza Hukuku Genel Hükümler, 491; Göktürk, "Türk Hukuku'nda Suçların İçtimaı”, 43.

44 Koca ve Üzülmez, Türk Ceza Hukuku Genel Hükümler, 481.

45 Koca ve Üzülmez, 494-95; Göktürk, “Türk Hukuku’nda Suçların İçtimaı”, 44.

46 Özgenç, Türk Ceza Hukuku, 585; Koca ve Üzülmez, Türk Ceza Hukuku Genel Hükümler, 499.

47 Özgenç, Türk Ceza Hukuku, 591; Koca ve Üzülmez, Türk Ceza Hukuku Genel Hükümler, 498.

48 Erturhan, İslam Ceza Hukukunda İçtima, 53; Fatma Karakaş Doğan, “Türk Ceza Hukukunda Cezaların İçtima1 Kurumunun Düzenlenmesi Gerektiği Üzerine”, Ankara Barosu Dergisi, sy 3 (2011): 87. 
cezaların af, zaman aşımı ve infaz gibi sebeplerle düşmemiş olması gerekmektedir. ${ }^{49}$ Cezaların içtima1, önceden Türk pozitif hukukunda (Mülga TCK md.68-80) kabul edilmiş iken son ceza kanununda cezaların içtimaı sistemine yer verilmemiştir. Nazariyede ise cezaların nasıl içtima edileceği ile ilgili üç sistemden bahsedilmektedir. Bunlardan ilki, erime sistemine göre fail, işlemiş olduğu suçlardan en ağır olanı için cezalandırılır. Failin işlediği daha hafif suçlar için öngörülen ceza veya cezaların, en ağır suça mukabil verilen cezanın içinde eridiği kabul edilir. Bu sistem, bazı suçların cezasız kalması, suçluların yeni birtakım suçlar işlemesine olanak vermesi açısından eleştirilmekle birlikte peş peşe ceza infazının getirdiği ağır sonuçları ortadan kaldırması bakımından da kabule şayan görülmüştür..$^{50}$ İkinci sistem ise cezaların arttırılması, hukuki içtima veya ağırlaştırma sistemi olarak isimlendirilen sistemdir. Bu sisteme göre işlenen suçlardan birine verilen ceza temel alınmakta, diğer suçlar için verilen cezaların ise bir kısmı buna eklenerek temel alınan ceza ağırlaştırılmaktadır. Böylece daha hafif suçların cezasız kalması engellenmeye çalışılmaktadır. Bu sistemi uygulayan pozitif hukuk sistemlerinde artırılmış cezalar için de önceden bir üst sınır belirlenmekte, ceza miktarı bu sınırı geçememektedir. ${ }^{51}$

Cezaların içtimaı konusunda takip edilen üçüncü sistem ise maddi içtima veya diğer adıyla cezaların toplanması sistemidir. Sistem, failin işlediği her bir suç için ayrı ayrı ceza alması ilkesine dayanmaktadır. Bu sistemde içtima, toplanan cezalar için bir üst sınırın belirlenmiş olmasıyla gerçekleşmektedir. ${ }^{52}$ Mülga TCK'de cezaların mümkün mertebe toplanması, toplama sisteminin daha ağır sonuçlara yol açacağı durumlarda ise ceza nev'inin değiştirilmesi ve toplanan cezaların türüne göre kanunda belirlenen üst sınırın aşılmaması kanunlaştırılmıştır. Türk ceza hukukunda 1953 yılında cezaların toplanması sistemine geçilmiştir. 2005 yılında yürüklüğe giren son ceza kanununda ise cezaların içtimaı sistemine yer verilmemiştir. ${ }^{53}$ Buna karşın hürriyeti bağlayıcı birden çok ceza alan fail için koşullu salıverme sistemi getirilmiştir. Buna göre maddi içtima neticesinde failin aldığ 1 cezaların toplamı belirli bir sınıra ulaştığında ve gerekli şartlar yerine geldiğinde failin koşullu salıverileceği kanunlaştırılmıştır. (İnfaz Kanunu, m. 107/2) ) $^{54}$

49 Erturhan, İslam Ceza Hukukunda İçtima, 54; Karakaş Doğan, "Türk Ceza Hukukunda Cezaların İçtimaı", 88.

50 Karakaş Doğan, “Türk Ceza Hukukunda Cezaların İçtimaı”, 89-90.

51 Karakaş Doğan, 90.

52 Karakaş Doğan, 91.

53 Erturhan, İslam Ceza Hukukunda İçtima, 58; Metin Feyzioğlu ve Devrim Güngör, "Cezaların Toplanması ve Koşullu Salıverilme İlişkisi”, Türkiye Barolar Birliği Dergisi, sy 69 (2007): 52; Karakaş Doğan, “Türk Ceza Hukukunda Cezaların İçtimaı”, 88.

54 Feyzioğlu ve Güngör, “Cezaların Toplanması ve Koşullu Salıverilme İlişkisi”, 52. 


\section{c- Fıkhî Açıdan Tedâhüi/İçtima ve Türk Pozitif Hukukuyla Mukayesesi}

Fikhî açıdan tedâhülde esas alınan nokta hak kavramıdır. Bu doğrultuda herhangi bir kişinin inhisarında olmayan, tüm insanlığın ortak faydasıyla alakalı haklar ve bunlara bağlı hükümlerde (hakku'l-lah) tedâhülün geçerli olduğu kabul edilmiştir. Bu tarifin dışında kalan, kulların haklarına (hakku'l-i‘bâd) ve bunlara dair hükümlerde ise tedâhülün geçerli olmadığg kabul edilmektedir. ${ }^{55} \mathrm{Bu}$ sebeple bir ceza davasında her iki hakkın söz konusu olması durumunda kul hakkını ihlal eden suç öncelenmektedir. Zira şahısların, kamuya nazaran korunmaya daha muhtaç ve daha güçsüz oldukları kabul edilmektedir. ${ }^{56} \mathrm{Bu}$ durum klasik literatürde, bir konuda hem kamu hakkı hem de şahıs hakkı söz konusu olduğunda şahsa ait hakların önceleneceği şeklinde ifade edilmektedir. ${ }^{57}$

Kamu hukukunu ihlal eden zina, hırsızlık, içki içme, kazf ve hirâbe suçlarında tedâhül, infaz öncesi ve söz konusu suçun aynı türden olması hâlinde gerçekleşmektedir. ${ }^{58}$ Örneğin bir şahıs hırsızlık suçunu birden fazla irtikap ettiğinde sadece tek bir ceza almaktadır. Bu durum günümüz Türk pozitif hukukundaki suçların içtimaından ziyade, cezaların içtimaı kapsamına girmektedir. Zira hırsızlık suçunu oluşturan fiil, zincirleme suçta olduğu gibi tek şahsa yönelik işlenmemekte veya fikrî içtimada olduğu gibi tek fiil ile değil, birden çok fiil ile işlenmektedir. Buna karşın özellikle Hanefî nazariyesinde birden fazla hırsızlık suçunu irtikap edene tek bir ceza verilmesi, cezaların tedâhül edildiğini göstermektedir. Lakin aynı suçun birden fazla kişiye karşı işlenmesini zincirleme suç olarak kabul eden eski TCK'ye göre birden fazla hırsızlık suçunu irtikap eden şahsa tek suçtan ceza verilmesi de zincirleme suç kapsamında girmektedir. Birden fazla kişiye aynı anda ve tek fiil ile zina iftirasında bulunan şahıs için de tek bir cezanın uygulanacağı

55 Erturhan, İslam Ceza Hukukunda İçtima, 80-81; Hasan ve Geylan, "İslam Ceza Hukukunda ve Pozitif Hukukta Aynı Amaca Yönelik Suçların Gerçek İçtimai”, 830; Literatürde kamuya ait maslahat ve menfaatler "hakkullah" terimi ile ifade edilmektedir. Burada hak teriminin Allah'a izafe edilmesinin mecazi olduğu ve hak teriminin kapsadığı alan içinde menfaatin tüm insanlığa ait olduğu ifade edilmektedir. Hak kavramı ile ilgili detaylı bir analiz için bkz.: Hasan Hacak, “İslam Hukukunun Klasik Kaynaklarında Hak Kavramının Analizi” (Doktora Tezi, İstanbul, Marmara Üniversitesi Sosyal Bilimler Enstitüsü, 2000), 97, 106; Ali Bardakoğlu, “Hak”, içinde TDV İslam Ansiklopedisi (İstanbul: TDV Yayınları, 1997), 142.

56 Alâüddîn Ebû Bekr b. Mes 'ûd b. Ahmed Kâsânî, Bedâiu's-sanâi 'fí tertîbi'ş-şerâi, 2. bs (Beyrut: Dâru'l-Kütübi'l-İlmiyye, 1986), 7:62-63.

57 ، لأن حق الله تعالى منى اجتمع مع حق العبد في محل يقدم حق العبد ، Alâüddîn Abdülazîz b. Ahmed b. Muhammed el-Buhârî, Keş̧ü'l-esrâr fi şerhi Usûli'l-Pezdevî (Kahire: Dâru'l-Kitâbi'l-İslâmî, t.y.), 4:311.

58 Cessâs, Şerhu muhtasari 't-Tahâvî, 2:425; Serahsî, el-Mebsût, 9:102; Kâsânî, Bedâiu's-sanâi ', 7:55-56; Aynî, el-Binâye, 5:564; Hasan ve Geylan, "İslam Ceza Hukukunda ve Pozitif Hukukta Aynı Amaca Yönelik Suçların Gerçek İçtimai”, 830; Avc1, "İslam ve Osmanlı Ceza Hukukunda İçtima", 4. 
ifade edilmektedir. ${ }^{59} \mathrm{Bu}$ örnekte tek fiil ile birden fazla kişiye yönelik aynı suç işlendiğinden aynı neviden fikrî içtimaın söz konusu olduğu söylenebilir.

Kamu hukukunu ihlal eden ve had cezası gerektiren birden fazla farklı suçun tedâhülü ise kabul edilmemektedir. Zira işlenen her bir suçun farklı hukuki değerleri ihlal ettiği, bu suçlara karşılık vazedilen cezaların da değişik amaçları gerçekleştirmeyi hedeflediği ve her bir ceza ile farklı hukuki değerlerin koruma altına alındığı ifade edilmektedir. ${ }^{60} \mathrm{Bu}$ sebeple suçların tedâhülü durumunda nasların amaçladığı hedeflerin ihmal edileceği söylenebilir. Örneğin bir kimse zina eder, içki içer ve zina iftirasında bulunursa her bir suç için ayrıca cezalandırılır. ${ }^{61}$ Lakin bir şahıs kamu hakkını ihlal eden bir suçla beraber kul hakkını ihlal eden başka bir suç daha işlediğinde, kul hakkının öncelenmesi prensibi gereğince ilk olarak kul hakkını ihlal eden suçun cezası infaz edilmektedir. ${ }^{62}$ Örneğin bir kimse kazf ile birlikte recm veya kısas gereği idam gerektiren herhangi bir suç işlediğinde recm veya kısas ile her hâlükârda öldürülecek olması gerekçesiyle kazf suçunun cezası düşürülmemektedir. Bunun gerekçesi olarak kazf suçunda kul hakkının da ihlal edilmiş olması gösterilmektedir. ${ }^{63} \mathrm{Bu}$ durumda doğrudan ölümle sonuçlanacak bir cezanın uygulanması hâlinde kul hakkının zayi olacă̆ 1 düşünülmektedir. Aynı şekilde ta'zir cezası gerektiren ve kul hakkını ihlal edici suçların birden fazla işlenmesi durumunda da tedâhül söz konusu değildir. ${ }^{64}$ Söz gelimi bir kişiye birden çok sözcükle hakaret edildiğinde bunlardan her biri için

59 İbnü'l-Hümâm, Feth'ul-kadîr, 5:327; Molla Hüsrev, Dürer, 2:72.

60 Erturhan, İslam Ceza Hukukunda İçtima, 136.

61 İbn-i Abdilberr en-Nemerî, Kâfi fi fikhi ehli'l-Medîneti 'l-Mâlikî, 2. bs (Riyâd: Mektebetü'r-Riyâd el-Hadise, 1980), 2:1075; Kâsânî, Bedâiu 's-sanâi ', 7:55-56; İbn Rüşd, Bidâyetü'l-müctehid ve nihâyetü'l-muktesıd (Kahire: Dâru'l-Hadis, 2004), 2:68; Ebû Muhammed Muhyissünne elHüseyn b. Mes'ûd b. Muhammed el-Ferrâ'Begavî, et-Tehzîb (Beyrut: Dâru'l-Kütübi'l-İlmiyye, 1997), 7:404; Zeylaî, Tebyînü'l-Hakaik, 3:207; Ekmelüddîn Muhammed b. Mahmûd b. Ahmed el-Bâbertî, el-İnâye şerhu'l-Hidâye (el-Hidâye ile birlikte) (Beyrut: Dâru'l-Fikr, t.y.), 5:340; Aynî, el-Binâye, 6:388; İbnü'l-Hümâm, Feth 'ul-kadîr, 5:340; İbn Nüceym, Bahru'r-râik, 5:42; Sirâceddin İbn Nüceym, en-Nehru'l-fâik şerhu kenzi'd-dekāik, 1. bs (Beyrut: Dâru Kitâbi'lİlmiyye, 2002), 3:163; Şemsüddîn Muhammed b. Ahmed el-Hatîb eş-Şirbînî, Muğni'l-muhtâc ilâ ma 'rifeti me 'ânî elfâzi'l-Minhâc (Beyrut: Dâru'l-Kütübi'l-İlmiyye, 1994), 5:496.

62 Erturhan, İslam Ceza Hukukunda İçtima, 142, 145; Avc1, "İslam ve Osmanlı Ceza Hukukunda İçtima”, 12.

63 Serahsî, el-Mebsût, 9:138; Kâsânî, Bedâiu's-sanâi ', 7:63; İbnü'l-Hümâm, Feth 'ul-kadîr, 5:341342.

" "Zeylaî, Tebyînü'l-Hakaik, 3:207; “" Muhammed Emîn b. Ömer b. Abdilazîz elHüseynî İbn Âbidîn, Reddü 'l-muhtâr ale'd-dürri'l-muhtâr, 2. bs (Beyrut: Dâru'l-Fikr, 1992), $4: 74$. 
ayrı bir ta 'zir cezası öngörülmektedir. ${ }^{65}$ Nazariyedeki bu hükümler Türk pozitif hukuku ile Hanefî fıkhının tedâhüle/içtimaa bakışındaki anlayış farkını ortaya koymaktadır. Türk pozitif hukukunda suçların içtima edilebilmesi için birden fazla norm ihlalinin tek bir suç olarak birleştirilebilmesinin imkânı aranmaktadır. Hanefî fikhında ise meydana gelen ihlallerin hangi hak türünü ihlal ettiği önemlidir. Örneğin, Türk pozitif hukuku açısından birçok farklı ifade ile aynı kişiye farklı zamanlarda hakaret edildiğinde zincirleme suç meydana gelecek ve bu suçlar içtima edilerek tek bir suça karşılık kanunda belirtilen oranda artırımla birlikte tek bir ceza verilecektir. ${ }^{66}$ Suçun birden fazla irtikap edilmiş olmasına rağmen her defasında aynı norm ihlalinin aynı kişiye karşı işlenmiş olmasının, suçların içtimaını mümkün kıldığı kabul edilmektedir. Hanefî fikhı açısından ise bu örnekte kulun hakkı ihlal edildiğinden suçlar tedâhül edilmemekte, her bir hakaret için ayrı ceza infaz edilmektedir. Hatta bu hakaretlerin farklı zamanda gerçekleşmiş olması şartı dahi aranmamış, aynı anda edilen her bir hakaret ayrı bir norm ihlali olarak değerlendirilmiştir.

\section{d- Tanzimat Sonrası Osmanlı Pozitif Hukukunda İçtima}

Osmanlı Devleti'nde içtima ile ilgili düzenlemeler yapan ilk kanun metni 1879 tarihli Usûl-i Muhâkemât-1 Cezaiyye Kanunu'dur. Kanunda içtima veya tedâhül tabirleri kullanılmamakla birlikte 299. maddede "birkaç cinâyet veya cünha birleşmiş olduğu halde yalnız en ağır cezayı istilzam eden cürme terettüp eden mücâzât tayin olunur" ifadesi yer almaktadır. ${ }^{67}$ Buradan anlaşıldığı üzere bir kişi kabahatler haricinde birden fazla suç işlediğinde, bunlardan sadece en ağır ceza gerektiren suça mukabil cezalandırılacaktır. Konu ile ilgili dönemin Mekteb-i Hukuk-1 Şahane hocalarından Mehmet Aziz, Avrupa ülkelerindeki içtima sistemleri hakkında bilgi vermekte, bazı ülkelerde suçların içtimaının kabul edilmediğini ve her suça mukabil cezanın ayrı ayrı infaz edildiğini, bazılarında ise genel kuralın bir istisnası olarak belirli suçlarda içtima sisteminin uygulandığını aktarmaktadır. Buna karşın o dönem içtima konusunda genel kabulün, birden çok suçların içtima edilerek en ağır cezayı gerektiren suç için öngörülen cezanın infaz edilmesi olduğunu ifade etmektedir. ${ }^{68}$

65 İbn Âbidîn, Reddü'l-muhtâr, 4:74.

66 Koca ve Üzülmez, Türk Ceza Hukuku Genel Hükümler, 482; Göktürk, “Türk Hukuku'nda Suçların İçtimaı", 42; Yalçın Sancar, "Yeni Türk Ceza Kanunu'nda 'Zincirleme Suç”, 249-53.

67 Usûl-i Muhâkemât-ı Cezaiyye Kanunu (İstanbul: Sancakçıyan Matbaası, 1296), 104.

68 Mehmet Aziz, Mufassal Nazariyat-ı Ceza (İstanbul: Şirket-i Mürettebiye Matbaası, 1316), 1058; Nugay, "XIX. Yüzyıl Ortak Ceza Hukuku Dilinin Oluşumu: Osmanlı'da Ta’zîrin Kalkması", 174. 
Her ne kadar burada suçların içtimaından söz edilse de aslında cezaların içtima edildiği anlaşılmaktadır. Usûl-i Muhâkemât-1 Cezaiyye Kanunu'nda yer alan metinden ve Mehmet Aziz'in ifadelerinden anlaşıldığı üzere cezaların içtimaında da erime sisteminin uygulandığ 1 görülmektedir. Zira birden çok ceza olmasına rağmen bunlardan en ağırının infaz edilmesi ile diğer cezalar, infaz edilen cezanın içinde erimektedir. İkinci bir husus, bugün Türk pozitif hukukunda kabul gören "kaç tane fiil varsa o kadar suç, kaç tane suç varsa o kadar ceza olduğu" anlayışının 19. yüzy1lda da mevcut olduğu, lakin genel kabul görmediğidir. Tanzimat sonras1 Osmanlı ceza hukuku üzerine yapılan bazı çalışmalarda ise 1879 tarihli Usûl-i Muhâkemât-1 Cezaiyye Kanunu öncesi içtima sisteminin bazı istisnai durumlar haricinde uygulanmadığ $1^{69}$ ifade edilmekteyse de gazetedeki hakaret suçu ile ilgili örneklerde içtimaa dair örnekler bulmak mümkündür. Gazetenin 1869 tarihinde yayımlandığı bilindiğine göre, içtima sisteminin kanunlarda yer almadan en az on yıl önce mahkemelerde uygulandığı söylenebilir.

Bu dönemde içtimain söz konusu olabilmesi için aranan temel şart, suçu oluşturan fiil veya fiillerin aynı kişi tarafından işlenmesi ve bu suçlar hakkında henüz bir hüküm verilmemiş olmasıdır. ${ }^{70}$ Bazıları ise suçlar hakkında hüküm verilmemiş olmasını değil, infazın gerçekleşmemiş olmasını baz almaktadır. ${ }^{71}$ Şartları taşıması hâlinde aynı veya farklı neviden olan suçları işleyen kişinin sadece en ağır suça mukabil cezalandırılacağı kabul edilmektedir. ${ }^{72}$ Cezanın çeşitli derecelere sahip olması durumunda ise hâkimin somut olayın koşullarına göre kanunda belirtilen sınır arasında bir tercih mi yapacağı, yoksa her hâlükârda cezanın en üst sınırının mı infaz edileceği tartışmalı bir konudur. İlgili kanun metninde de hangi yolun takip edileceği ile alakalı bir ifade bulunmamaktadır. ${ }^{73}$ Dönemin Osmanlı hukukçuları ise somut olayın koşullarına göre hâkimin kanunda belirtilen sınırlar içerisinde bir tercih yapacağı görüşünü benimsemişlerdir. ${ }^{74}$ İçtima ile ilgili dönemin hukuk eserlerine ve kanun metinlerine bakıldığında henüz suçların ve cezaların içtimaının birbirinden

69 Nugay, “XIX. Yüzyıl Ortak Ceza Hukuku Dilinin Oluşumu: Osmanlı' da Ta’zîrin Kalkması”, 175.

70 Nazeret Haçariyan., Mebâdi-i Hukuk-ı Ceza (İstanbul: Şirket-i Mürettebiye Matbaası, 1306), 103; Aziz, Mufassal Nazariyat-ı Ceza, 103; Nugay, “XIX. Yüzy1l Ortak Ceza Hukuku Dilinin Oluşumu: Osmanlı'da Ta'zîrin Kalkması", 176.

71 Fahreddin, Memnu' Fiillerin ve Cezalarının İctimâı (İstanbul: Yeni Matbaa, 1926), 3.

72 İçtima uygulanırken hangi cezanın daha ağır, hangisinin daha hafif olduğu ile ilgili detaylı bilgi için bkz.: Nugay, 'XIX. Yüzyıl Ortak Ceza Hukuku Dilinin Oluşumu: Osmanlı'da Ta’zîrin Kalkması”, 177.

73 Usûl-i Muhâkemât-ı Cezaiyye Kanunu, 104, md. 299.

74 Aziz, Mufassal Nazariyat-ı Ceza, 114; Nugay, “XIX. Yüzyıl Ortak Ceza Hukuku Dilinin Oluşumu: Osmanlı'da Ta'zîrin Kalkması”, 179-80. 
ayrılmadığ görülmektedir. Bu eserlerden birinin müellifi olan Nazeret Haçariyan, suçların ve cezaların içtimaını birbirinden ayırmakla birlikte yaygın ve aslolanın cezaların içtimaı olduğunu söylemekte ve bunun üzerinde durmaktadır. ${ }^{75}$ Buradan da anladığımız kadarıyla o dönemde içtimadan anlaşılan cezaların içtimaıdır.

Gazetede hakaret suçlarında doğrudan içtimaın uygulandığı beş adet dava kaydı bulunmakta ve bunların tamamında cezalar içtima ettirilmektedir. Bunlardan ilki, 5 Rebîülâhir 1286 (15 Haziran 1869) tarihli on beşinci sayıda yer almaktadır. Burada yer alan dava kaydına göre Baş Kurşunlu Medresesi ${ }^{76}$ talebelerinden biri, tartıştığ 1 bir şahsı topuz ile darp etmiş ve sözlü olarak şahsın namusunu ihlal etmiştir. Muhakeme sonucu namusa hakaret suçu "sebeb-i şiddet" addedilerek darp suçuna mukabil Ceza Kanunnâmesi'nin 179. maddesince zanlının bir ay hapsine hükmedilmiştir. ${ }^{77}$ İkincisi ise 9 Rebiülahir 1286 (19 Haziran 1869) tarihli on altıncı sayıda zikredilen bir dava kaydıdır. Buna göre, bir kadının namusuna halel getirici söz söyleyen ve öfke ile kadını darp eden kişiye, namusa hakaret suçu "sebeb-i şiddet tutularak" sadece darp suçuna mukabil Ceza Kanunnâmesi'nin 179. maddesi hükmünce on beş gün hapis cezası verilmiştir. Hakaret suçu kapsamında içtimaın uygulandığı üçüncü kayıt ise gazetenin 29 Recep 1286 (4 Kasım 1869) tarihli kırk beşinci sayısında yer almaktadır. Dava kaydında yer alan bilgilere göre, Şükrü isimli şahıs, Aziz isimli bir şahsı darp etmiştir. Aziz ise buna karş11ık vererek Şükrü' yü sekiz günde iyileşecek derecede yaralamış ve Sadık isimli şahsın namusuna dokunacak söz söylemiştir. Bu sebeple Aziz'e, hakaret suçu "sebeb-i şiddet tutularak" yaralama suçundan dolayı Ceza Kanunnâmesi'nin 179. maddesi gereğince on iki gün hapis cezası verilmiştir. ${ }^{78} \mathrm{Bu}$ dava kaydını ilk iki örnek dava kaydından ayıran özellik, farklı suçların yöneldiği kişilerin de farklı olmasıdır. Dördüncü dava kaydı, gazetenin 4 Şaban 1286 (4 Kasım 1869) tarihli kırk altıncı sayısında yer almaktadır. Kayıtta ifade edildiğine göre, bir şahıs üvey babasının namusunu ihlal edip annesini de sekiz günde iyileşecek şekilde yaralamıştır. Bu sebeple zanlıya, namusa hakaret etmesi "sebeb-i şiddet tutularak" yaralama suçundan dolayı Ceza Kanunnâmesi 179. maddesi hükmünce iki ay hapis cezası verilmiştir. ${ }^{79}$ Bu kayıtta da suçlar tek bir kişiye değil, farklı kişilere yönelik işlenmiştir. Son olarak, 21 Şaban 1286 (26 Kasım 1869) tarihli kırk dokuzuncu sayısında yer verilen kayda göre, bir kadının namusunu halel edici söz söyleyip kadını taş atmak suretiyle yaralayan şahsa,

75 Nazeret Haçariyan., Mebâdi-i Hukuk-ı Ceza, 103.

76 Medrese hakkında detaylı bilgi için bkz.: Fahri Unan, "Sahn-1 Semân”, içinde TDV Íslam Ansiklopedisi (İstanbul: TDV Yayınları, 2008), 532.

77 Vakâyi-i Zabtiye, 15/3, M.T. Dersaâdet.

78 Vakâyi-i Zabtiye, 45/2, M.T. Üsküdar.

79 Vakâyi-i Zabtiye, 46/3, M.T. Dersaâdet. 
namusa hakaret etmesi "sebeb-i şiddet tutularak" yaralama suçuna karş11ık Ceza Kanunnâmesi 179. maddesince on gün hapis cezası verilmiştir. ${ }^{80}$

Görüldüğü üzere örnek dava kayıtlarında aynı kişiler birden fazla farklı suç işlemişlerdir. Bunların iki tanesinde hakaret suçu darp suçu ile birlikte, diğer üçünde ise yaralama suçu ile birlikte işlenmiştir. Kırk beş ve kırk altıncı sayılarda yer alan dava kayıtlarında ise diğerlerinden farklı olarak suçlar birden fazla kişiye karşı işlenmiştir. Faillerin hem işledikleri hakaret suçu için hem de bu suçla birlikte işledikleri darp veya yaralama suçları için ceza kanununda düzenlemeler mevcuttur. Namusu ihlal şeklinde tanımlanan şetm suçuna mukabil 214. maddede, darp ve yaralama suçuna karşıllk ise 179. maddede gerekli düzenlemeler yapılmıştır. Lakin yapılan muhakemelerde faillere, işledikleri şetm suçuna mukabil bir ceza verilmemiş, bu suç yaralama veya darp suçunun cezası için artırım sebebi sayılmıştır. Şetm suçunun cezası yukarıda da ifade edildiği üzere yirmi dört saatten bir aya kadar hapis cezasıdır. ${ }^{81}$ Yaralama veya darp suçunu düzenleyen Ceza Kanunnâmesi'nin 179. maddesi ise yirmi günden az sürede işten geri kalmaya sebep olacak derecede yaralama ve darp suçları ile ilgili hükümleri içermektedir. Bu şekilde bir yaralama veya darp fiilinde faile bir hafta ile bir sene arasında hapis cezası verileceği, suçun önceden tasarlanarak işlenmesi hâlinde ise bu miktarın bir ay ile iki seneye kadar uzatılacağı ifade edilmektedir. ${ }^{82}$ Örnek dava kayıtlarından anlaşıldığı üzere darp veya yaralama fiilleri, hiçbir örnek olayda önceden planlanarak gerçekleşmemiştir. Bu sebeple kanun gereği faillerin bir hafta ile bir sene arasında hapis cezası alması gerekmektedir.

Mahkemelerin içtima sisteminin uygularken nasıl bir yol izlendiğini anlamak için her iki cezanın mahiyetine bakmak gerekmektedir. Cezaları düzenleyen 1858 Ceza Kanunnâmesi'nin ilk maddelerinde cezalar genel olarak taksim edilmekte ve cinâyât, cünha ve kabâhat olmak üzere üçe ayrılmaktadır. Üçüncü maddede tanımlanan cinâyetler, mücâzât-ı terhîbiyeyi gerektiren suçlardır. Mücâzât-ı terhîbiye ise teşhir ile birlikte idam, müebbet veya muvakkat kürek, kalebentlik ve benzeri cezalardır. Cünha, dördüncü maddede ele alınmakta ve bu suçların mücâzât-ı tedibiyyeyi gerektirdiği belirtilmektedir. Mücâzât-ı tedibiyye ise nakdî para cezas1 ve bir haftadan fazla hapis gibi cezalardır. ${ }^{83}$ Kabâhat ise beşinci maddede ele alınmakta ve muâmele-i tekdiriyyeyi müstelzim cezalar olarak ifade edilmektedir. Muâmele-i tekdiriyye de yüz kuruşa kadar olan para cezası ve yirmi dört saatten bir haftaya kadar hapis cezası olarak tanımlanmaktadır. ${ }^{84}$

80 Vakâyi-i Zabtiye, 49/3, M.T. Dersaâdet.

81 Ceza Kanunnâme-i Humâyunu, 100.

82 Ceza Kanunnâme-i Humâyunu, 81.

83 Ceza Kanunnâme-i Humâyunu, 3.

84 Ceza Kanunnâme-i Humâyunu, 3-4. 
Yapılan bu taksimattan hareketle, darp/yaralama suçuna mukabil kanunda öngörülen hapis cezasının alt sınırı bir haftadan başladığından darp/yaralama suçunun bir cünha olduğu ifade edilebilir. Lakin şetm suçu için kanunda yirmi dört saat ile bir ay arası hapis cezası öngörüldügünden, bu suçun bir kabahat mı yoksa cünha mı olduğu anlaşılmamaktadır. ${ }^{85}$ Şayet hakaret suçunu da bir cünha olarak kabul edecek olursak, ceza miktarının tayininde mahkemelerin, miktarı çok olan cezayı esas aldıklarını söyleyebiliriz. Bunu bir kabahat olarak kabul ettiğimizde ise mahkemelerin, cezası ağır olanı esas aldıkları söylenebilmektedir. Son ihtimalde, davaların görüldüğü tarihten on y1l kadar sonra yürürlüğe konulan 1879 tarihli kanunda belirtildiğinin aksine, içtimaın kabahatleri de kapsayacak şekilde uygulanması söz konusu olacaktır.

1858 tarihli Ceza Kanunnâmesi'nde katl (min gayr-i teammüd) suçunun başka cinayet ve cünhalarla birlikte işlenmesi hâlinde kürek cezasının idama çevrileceği ifade edilerek içtima sistemi uygulanmıştır. ${ }^{86}$ Lakin her ne kadar 1858 Ceza Kanunnâmesi'nde içtima sadece katl ile ilgili düzenlenmişse de uygulamada hakaret suçlarında da içtima sisteminin uygulandığı görülmektedir. Bununla beraber mahkeme kayıtlarında doğrudan içtima veya tedâhül terimleri kullanılmamaktadır. Ceza kanununda içtima ile ilgili düzenlemelere yer verilmemesi, 1879 tarihli usul kanununda yer verilen içtima sisteminin bu tarihe kadar uygulanmadığı şeklinde yanlış bir kanaate yol açabilmektedir. ${ }^{87}$ Fakat gazetedeki dava kayıtlarından hareketle kanunlaştırma sonrası dönemde, her ne kadar kanun metinlerinde yer verilmese de uygulamada içtima sisteminin uygulandığı görülmektedir.

Gazetede doğrudan içtima sisteminin uygulanmadığ lakin içtima mantığının işletildiği bazı dava kayıtlarına da rastlanmaktadır. Tespit edebildiğimiz kadarıyla hakaret suçu ile ilgili fikrî içtimaın söz konusu olabileceği yirmi adet dava kaydı bulunmaktadır. Bunlardan bir tanesi namusu halel edici fiilde bulunma şeklinde gerçekleşmiştir. Gazetenin 7 Rebiülevvel 1286 (17 Haziran 1869) tarihli yedinci sayısında yer alan bir dava kaydına göre, ihtiyar bir imam ile kunduracı bir şahıs, karı koca iki kişinin namusunu halel edici birtakım hareketlerde bulunmuşlardır. $\mathrm{Bu}$ sebeple faillerden ihtiyar olanın yaşı göz önünde bulundurularak iki adet

85 Konu üzerine detaylıca yapılan bir çalışmada, bu sorunun mezkûr ceza kanunnamesinin mehazı Fransız Ceza Kanunu'ndan (Code Pénal 1810) kaynaklandığı ve aynı sorunu Fransız Ceza Kanunu'nu uygulayan başka ülkelerin de yaşadığı ifade edilmektedir. Nugay, "XIX. Yüzyıl Ortak Ceza Hukuku Dilinin Oluşumu: Osmanlı'da Ta’zîrin Kalkması”, 124.

86 Ceza Kanunnâme-i Humâyunu, 79.

87 Nugay, “XIX. Yüzyıl Ortak Ceza Hukuku Dilinin Oluşumu: Osmanlı'da Ta'zîrin Kalkması”, 183. 
yüzlük altın para cezası ödemesine, diğerinin ise bir ay hapsine hükmedilmiştir. ${ }^{88}$ Kayıttan anlaşıldığ kadarıyla hakaret suçu birden fazla kişiye karşı işlenmiştir. $\mathrm{Bu}$ durum günümüz Türk pozitif hukuku açısından aynı neviden fikrî içtima kapsamında değerlendirilebilir. Kayıtta suça mukabil verilen cezalara bakıldığında ise hapis cezasının kanunda belirtilen miktarın en üst sınırından verildiği, para cezasının ise en üst sınıra yakın olduğu görülmektedir. Burada hâkimin somut olayın şartlarına göre takdir yetkisini kullandığı, tarafların birden fazla olması sebebiyle cezaları üst sınırdan verdiği söylenebilir. Böylece her ne kadar örnek dava kaydında lafzen içtima sistemini ifade edecek terimler kullanılmamış ve teorik bir içtima sitemi uygulanmamış olsa da verilen hükümde içtima mantığının izlerini görebilmek mümkündür. Diğer on dokuz kaydın dokuz tanesinde faillere, namusa hakaret suçundan dolayı hapis cezası, on tanesinde ise para cezası verilmiştir. ${ }^{89}$ Bu kayıtların tamamında hakaret suçu, bir suçun icrası kapsamında birden fazla kişiye veya bir gruba yönelik işlenmiştir. Dolayısıyla bu örnek dava kayıtları da bugünkü Türk pozitif hukukunda uygulanan aynı neviden içtima kapsamında değerlendirilebilir. Verilen ceza miktarlarına bakıldığında ise mahkemelerin, somut olayın şartlarına göre kanunda belirlenen sınırlar içerisinde takdir yetkilerini kullandıkları görülmektedir. Lakin her dava kaydında mağdurların birden fazla olması sebebiyle ceza artırımına gidildiği ve içtima mantığının uygulandığını söylemek mümkün değildir.

Gazetede hakaret suçu ile ilgili farklı neviden fikrî içtimaa örnek olabilecek kayıtlara ve zincirleme suç örneklerine rastlayamadık. Bir şahsın tek bir fiil ile birden fazla işlemiş olduğu suçlar veya aynı suçu birden fazla işlemesi ayrı ayrı muhakeme edilmiş ve bunlar da farklı tutanaklarda yer almış olabilir. Gazetenin, İstanbul mahkemelerinde görülen davalar içerisinden seçilerek yayımlandığı da göz önünde bulundurulduğunda, zincirleme suça veya farklı neviden fikrî içtimaa örnek olabilecek suçların gazetede yer almama sebebi anlaşılmaktadır. Bununla beraber gazetenin yayımlandığı dönemde bu türden içtima anlayışlarının olmaması sebebiyle, birden fazla suça aynı dava tutanağında yer verilmemiş olması da imkân dahilindedir.

\section{Sonuç}

Tanzimat Dönemi'nde nizamiye mahkemelerinin kurulmasıyla birlikte bu yeni mahkemelerin, yargılamaları yine bu dönemde hazırlanan kanunlara göre yapması istenmiştir. Fakat bu dönemde, yeni bir hukuk sistemine geçiş ve kanun

88 Vakâyi-i Zabtiye, 7/3, M.T. Beyoğlu.

89 Bu kayıtlar gazetenin 3, 11, 12, 13, 22, 32, 33, 35, 43, 45, 46 ve 49. sayılarında çeşitli mahkemelere ait başlıklarda yer almaktadır. 
yapımındaki tecrübesizlik ve eksiklikler sebebiyle birtakım hukuki boşluklar söz konusu olmuştur. $\mathrm{Bu}$ hukuki boşluklar ise mahkemelerin ilgili kanun maddelerini yorumlaması marifetiyle doldurulmuş gözükmektedir. Örneğin kanunda yer almasa dahi şetm suçunun yazılı olarak oluşabileceği yönündeki mahkeme kararı, bu suçun cezalandırılması ile korunan hukuki değerin (namusun) dikkate alınarak ilgili kanun maddesinin yorumlandığını göstermektedir. Yine kanun metninde yer almayan lakin namusu ihlal eden çeşitli hareketlerin şetm suçu kapsamında değerlendirilmesi de bunun bir göstergesidir. Tüm bunlar dikkate alınarak uygulamada tecrübe edinilen hususlar zamanla kanuna eklenmiştir.

Hakaret/şetm suçu özelinde içtima sistemi ele alındığında ise bu dönemde daha soyut bir sistem olan suçların içtimaının henüz gelişmemiş olduğu görülmektedir. Birden çok suçun meydana gelmesi durumunda ise suçların içtimaından çok cezaların nasıl toplanabileceği üzerinde durulmuştur. Gazetede yer alan dava kayıtlarından hareketle bu dönemde cezaların içtimaı sisteminde hukuki içtima, cezaların arttırılması veya ağırlaştırma olarak adlandırılan sistemin uygulandığı söylenebilir. Zira dava kayıtlarının tamamında aynı veya farklı kişilere karşı işlenen suçlardan sadece birine ceza verilmiş, diğer suç ise cezasız bırakılmayarak esas alınan cezanın arttırılmasına sebep sayılmıştır. Bunun, 1879 tarihli Usûl-i Muhâkemât-1 Cezaiyye Kanunu 299. maddesinde belirtilen içtima sisteminden farklı olduğu görülmektedir. Böylece Tanzimat sonrası dönemde her ne kadar kanun metinlerinde yer almasa da ilk olarak hukuki içtima sisteminin uygulandığını, lakin 1879 tarihinde Usûl-i Muhâkemât-1 Cezaiyye Kanunu'nda yer alan düzenleme ile erime sistemine geçildiği söylenebilir.

Genel olarak gazetede içtima sisteminin uygulandığ davalara bakıldığında ise konu ile alakalı fikhî nosyonun dikkate alınmadığı söylenebilir. Zira özellikle Hanefî fikhında birden fazla suçun mevcut olduğu durumlarda suçun yöneldiği hak/ hukuk türü dikkate alınmaktadır. Gerek gazetede hakaret suçları ile ilgili davalarda uygulanan hukuki içtima sisteminde gerekse usul kanununda kabul edilen erime sisteminde fikhî tecrübenin değil, Batı hukukunun esas alındığı anlaşılmaktadır. Dönemin hukuk bilginlerinin eserlerinde içtima konusunu ele alış şekilleri de bunu destekler niteliktedir. Bu eserlerde klasik fikıh kitapları veya nevâzil, vâkıât ve fetâvâ türü eserlerden ziyade Batı hukuk bilginlerinin eserleri dikkate alınmış, fikhın konuya nasıl yaklaştı̆ğ göz ardı edilmiştir. Örneğin gazetede yer alan bazı dava kayıtlarında, hem bir şahsa yönelik namusa hakaret suçunu hem de darp suçunu işleyen kişilere yönelik cezalar, hukuki içtima sistemi uygulanarak verilmiştir. Hâlbuki bu durumda Hanefî̀ mezhebine uygun olan, cezaların maddi içtimaıdır. Zira her iki suç türü de kul hakkına yönelik işlenmektedir. Hanefî fikhı, zedelenen hak açısından konuya bakıp kişilere ait hakların mümkün mertebe zail 
olmamasını amaçlanmaktayken modern hukukun, suçlunun ağır yaptırımlara maruz kalmaması açısından konuya yaklaştığı görülmektedir. Dolayısıyla gazetenin yayımlandığı dönemde fikhın değil, Batı hukukuna ait bakış açısının benimsendiği söylenebilir. Tüm bunlar Tanzimat sonrası dönemde hukuk anlayışında yaşanan değişimi göstermektedir. Bu dönemde fikıh; ilk olarak içtima gibi teknik konularda dikkate alınmamış, devam eden süreçte ise fikhın tamamen göz ardı edildiği bir sisteme geçilmiştir.

Hakem Değerlendirmesi: Dış bağımsız.

Çıkar Çatışması: Yazar çıkar çatışması bildirmemiştir.

Finansal Destek: Yazar bu çalışma için finansal destek almadığını beyan etmiştir.

Peer-review: Externally peer-reviewed.

Conflict of Interest: The author has no conflict of interest to declare.

Grant Support: The author declared that this study has received no grant support.

\section{Kaynakça/References}

Ahmet Lütfi. Kanun-ı Cedîd (Mirât-ı Adalet İçerisinde). İstanbul: Matbaa-i Nişân Berberyan, 1304. Akgündüz, Ahmet. Ceza Kanunnâme-i Humâyûnu (Mukayeseli İslâm ve Osmanlı Hukuku Külliyatı İçerisinde). Diyarbakır: Dicle Üniversitesi Hukuk Fakültesi Yayınları, 1986.

Ali Efendi, Şeyhülislam Çatalcalı. Açıklamalı Osmanlı Fetvaları. Editör H. Necati Demirtaş. İstanbul: Kubbealtı Neşriyat, 2011.

Avcı, Mustafa. "İslam ve Osmanlı Ceza Hukukunda İçtima”. Kırıkkale Hukuk Mecmuası 1, sy 1 (2021): 1-30.

. Osmanlı Ceza Hukuku Özel Hükümler. 3. bs. Ankara: Adalet Yayınevi, 2018.

Aydın, Devrim. "Türk Ceza Kanunu'nda Hakaret Suçu”. Marmara Üniversitesi Hukuk Fakültesi Hukuk Araştırmaları Dergisi 19, sy 2 (2013): 879-918.

Aydın, Mehmet Âkif. "Batılılaşma”. İçinde TDV İslam Ansiklopedisi, 5:162-67. İstanbul: TDV Yayınları, 1992.

Aynî, Bedruddin. el-Binâye şerhu'l-Hidâye. 13 c. Beyrut: Dâru'l-Kütübi'l-İlmiyye, 2000.

Aziz, Mehmet. Mufassal Nazariyat-ı Ceza. İstanbul: Şirket-i Mürettebiye Matbaası, 1316.

Bâbertî, Ekmelüddîn Muhammed b. Mahmûd b. Ahmed. el-İnâye şerhu'l-Hidâye (el-Hidâye ile birlikte). 10 c. Beyrut: Dâru'l-Fikr, t.y.

Bardakoğlu, Ali. "Hak”. İçinde TDV İslam Ansiklopedisi, 15:139-51. İstanbul: TDV Yayınları, 1997. Başoğlu, Tuncay. “Ta'zir”. İçinde TDV İslam Ansiklopedisi, 40:198-202. İstanbul: TDV Yayınları, 2011. Baytemir, Erdal. Cinsel Dokunulmazlı̆̆a, Kişi Hürriyetine ve Genel Ahlaka Karşı Suçlar. Ankara: Adalet Yayınevi, 2007.

Begavî, Ebû Muhammed Muhyissünne el-Hüseyn b. Mes'ûd b. Muhammed el-Ferrâ'. et-Tehzîb. 8 c. Beyrut: Dâru'l-Kütübi'l-İlmiyye, 1997. 
Bilmen, Ömer Nasuhi. Hukūk-ı İslâmiyye ve Istılâhât-ı Fıkhiyye Kāmusu. 8 c. İstanbul: Ravza Yayınları, 2013.

Boşgezenyan, Artin. Kanun-ı Cezanın Mevâdd-ı Kâime ve Muaddelesi Hakkında Teşrih ve Tenkit. İstanbul: Matbaa-1 Âmire, 1327.

Boynukalın, Mehmet. "Sövme”. İçinde TDV İslam Ansiklopedisi, 37:397-98. İstanbul: TDV Yayınları, 2009.

Buhârî, Alâüddîn Abdülazîz b. Ahmed b. Muhammed. Keşfü'l-esrâr fì şerhi Usûli'l-Pezdevî. 4 c. Kahire: Dâru'l-Kitâbi'l-İslâmî, t.y.

Cessâs, Ahmed b. Ali Ebubekr er-Râzî. Şerhu muhtasari't-Tahâvî. 8 c. Beyrut: Dâru'l-Beşâiri'lİslâmiyye, 2010.

Ceza Kanunnâme-i Humâyunu. İstanbul: Matbaa-1 Osmâniye, 1300.

Damad Efendi, Abdurrahman b. Muhammed b. Süleyman. Mecmau 'l-enhur fí şerhi mülteka 'l-ebhur. 2 c. Beyrut: Dâru İhyai't-Turasi'l-Arabî, t.y.

Demirtaş, H. Necati. Fetvalarl ile Şeyhülislam Ebüssu'ud Efendi. İstanbul: Akıl Fikir Yayınları, 2016.

Doğan, Recep. "Hakaret Suçu ve AİHM Kararlarında İfade Özgürlüğünün Sınırları”. Uyuşmazlık Mahkemesi Dergisi, sy 17 (2021): 191-239.

Erdoğan, Mehmet. Fıkıh ve Hukuk Terimleri Sözlüğü. 4. bs. Ensar Neşriyat, 2013.

Erturhan, Sabri. İslam Ceza Hukukunda İçtima. İstanbul: Rağbet Yayınları, 2003.

Fahreddin. Memnu' Fiillerin ve Cezalarının İctimâı. İstanbul: Yeni Matbaa, 1926.

Feyzioğlu, Metin, ve Devrim Güngör. “Cezaların Toplanması ve Koşullu Salıverilme İlişkisi”. Türkiye Barolar Birliği Dergisi, sy 69 (2007): 51-54.

Feyzullah Efendi, Şeyhülislam. Fetava-yı Feyziye. İstanbul: Klasik Yayınları, 2009.

Gayretli, Mehmet. Tanzimat'tan Cumhuriyet'e Kanunlaştırma Çalışmaları. İstanbul: Nizamiye Akademi, 2015.

Göktürk, Neslihan. “Türk Hukuku'nda Suçların İçtimaı”. Ceza Hukuku ve Kriminoloji Dergisi 2, sy 1-2 (2014): 31-59.

Hacak, Hasan. “İslam Hukukunun Klasik Kaynaklarında Hak Kavramının Analizi”. Doktora Tezi, Marmara Üniversitesi Sosyal Bilimler Enstitüsü, 2000.

Hasan, Taha Hamid, ve Ahmed Geylan. "İslam Ceza Hukukunda ve Pozitif Hukukta Aynı Amaca Yönelik Suçların Gerçek İçtimai”. İçinde İslam Ceza Hukuku, editör Abdurrahman Eren ve Refik Korkusuz, çeviren Osman Güman, 826-45. İstanbul: Lale Yayıncılık, 2017.

Haskefî, Alâüddîn Muhammed b. Alî b. Muhammed. ed-Dürrü'l-muhtâr şerhu tenvîri'l-ebsâr ve Câmii'l-bihâr. Beyrut: Dâru'l-Kütübi'l-İlmiyye, 2002.

İbn Âbidîn, Muhammed Emîn b. Ömer b. Abdilazîz el-Hüseynî. Reddü 'l-muhtâr ale'd-dürri'l-muhtâr. 2. bs. 6 c. Beyrut: Dâru'l-Fikr, 1992.

İbn Nüceym, Sirâceddin. en-Nehru'l-fâik şerhu kenzi'd-dekāik. 1. bs. 7 c. Beyrut: Dâru Kitâbi'lİlmiyye, 2002.

İbn Nüceym, Zeynüddin. Bahru'r-râik şerhu kenzi'd-dekāik (Tekmiletü Tûrî ve Minhatü'l-hâlik ile Birlikte). 8 c. Kahire: Dâru'l-Kitâbi'l-İslâmî, t.y.

İbn Rüşd. Bidâyetü'l-müctehid ve nihâyetü'l-muktesıd. 4 c. Kahire: Dâru'l-Hadis, 2004.

İbnü'l-Hümâm, Kemalüddin. Feth'ul-kadîr. 10 c. Beyrut: Dâru'l-Fikr, 1970. 
İbnü’ş-Şıhne, Lisânüddin. Lisânü'l-hükkâm fì ma 'rifeti'l-ahkâm. Kahire: el-Bâbî el-Halebî, 1973.

Karakaş Doğan, Fatma. "Türk Ceza Hukukunda Cezaların İçtimaı Kurumunun Düzenlenmesi Gerektiği Üzerine”. Ankara Barosu Dergisi, sy 3 (2011): 86-104.

Kâsânî, Alâüddîn Ebû Bekr b. Mes'ûd b. Ahmed. Bedâiu's-sanâi 'fí tertîbi'ş-şerâi. 2. bs. 7 c. Beyrut: Dâru'l-Kütübi'l-İlmiyye, 1986.

Koca, Mahmut, ve İlhan Üzülmez. Türk Ceza Hukuku Genel Hükümler. 6. bs. Ankara: Seçkin Yayınc1lık, 2013.

—. Türk Ceza Hukuku Özel Hükümler. Ankara: Adalet Yayınevi, 2013.

Koç, Mehmet. "Osmanlı Hukukunda Ta'zir Suç ve Cezaları”. Doktora Tezi, Necmettin Erbakan Üniversitesi Sosyal Bilimler Enstitüsü, 2017.

Köken, Enes. "Şerefe Karşı Suçlar”. Uyuşmazlık Mahkemesi Dergisi, sy 6 (2016): 281-309.

Kudûrî, Ebü'l-Hüseyn Ahmed b. Ebî Bekr Muhammed b. Ahmed el-. et-Tecrîd. 2. bs. 12 c. Kahire: Dâru's-Selâm, 2006.

Küveyt Vakıflar ve Din İşleri Bakanlığı. el-Mevsûatü'l-Fıkhiyyeti'l-Kuveytiyye. 45 c. Kuveyt: Dârü's-Selâsil, 1404.

Mehmed Reşâd. Mi'yâr-ı Ceza: Kanun-ı Ceza Şerhi. İstanbul: Dâru't-Tıbâati'l-Âmire, 1303.

Molla Hüsrev, Mehmed b. Ferâmuz. Dürerü'l-hükkâm şerhu gureri'l-ahkâm. 2 c. Dâr-u İhyai'lKütübi'l-Arabî, t.y.

Nazeret Haçariyan. Mebâdi-i Hukuk-ı Ceza. İstanbul: Şirket-i Mürettebiye Matbaası, 1306.

en-Nemerî, İbn-i Abdilberr -. Kâfî fí fikhi ehli'l-Medîneti'l-Mâlikî. 2. bs. 2 c. Riyâd: Mektebetü'rRiyâd el-Hadise, 1980.

Nugay, Kübra. “XIX. Yüzyıl Ortak Ceza Hukuku Dilinin Oluşumu: Osmanlı'da Ta’zîrin Kalkması”. Doktora Tezi, Marmara Üniversitesi Sosyal Bilimler Enstitüsü, 2020.

Özgenç, İzzet. Türk Ceza Hukuku Genel Hükümler. 11. bs. Ankara: Seçkin Yayınc1lık, 2015.

Sami Bey. Mirât-ı Kanun-ı Ceza: Kanun-ı Ceza Şerhi. 2. bs. Dersaadet: Matbaa-i Kütübhane-i Cihan, 1324.

es-Serahsî, Ebû Bekr Muhammed b. Ebî Sehl Ahmed-. el-Mebsût. 30 c. Beyrut: Dâru'l-Marife, 1993.

Şentop, Mustafa. Tanzimat Dönemi Osmanlı Ceza Hukuku: Kanunlar-Tadiller-Layihalar-Uygulama. İstanbul: Yaylacık Matbaas1, 2004.

eş-Şirbînî, Şemsüddîn Muhammed b. Ahmed el-Hatîb. Muğni 'l-muhtâc ilâ ma 'rifeti me 'ânî elfâzi'lMinhâc. 6 c. Beyrut: Dâru'l-Kütübi'l-İlmiyye, 1994.

Tatar, Bülent. “Türk Ceza Hukukunda Hakaret Suçları (Şerefe Karşı Suçlar)”. Doktora Tezi, Marmara Üniversitesi Sosyal Bilimler Enstitüsü, 2009.

Tevfik Tarık. Yeni Kanun-ı Ceza. Dersaadet: Şems Matbaası, 1329.

Unan, Fahri. "Sahn-1 Semân”. İçinde TDV İslam Ansiklopedisi, 35:532-34. İstanbul: TDV Yayınları, 2008. Usûl-i Muhâkemât-ı Cezaiyye Kanunu. İstanbul: Sancakçıyan Matbaası, 1296.

Yalçın Sancar, Türkan. "Yeni Türk Ceza Kanunu'nda 'Zincirleme Suç'”. Türkiye Barolar Birliği Dergisi, sy 70 (2007): 244-59.

Yerganyan, Diran. Kanun-l Ceza Dersleri. 2. bs. 2 c. Dersaadet: Becidyan Matbaas1, 1326.

Zeylaî, Osman b. Ali. Tebyînü'l-Hakāik Şerhu Kenzi'd-Dekāik (Şelebî'nin Hâsşiyesiyle Birlikte). 6 c. Kahire: Dâru'l-Kitâbi'l-İslâmî, 1896. 